\title{
MEGA-NOURISHMENTS AND AEOLIAN DEVELOPMENTS: LESSONS LEARNED SIX YEARS INTO THE SANDMOTOR PILOT PROJECT
}

\author{
Kathelijne Wijnberg, University of Twente, k.m.wijnberg@utwente.nl \\ Juul Limpens, Wageningen University \& Research, juul.limpens@wur.nl \\ Corjan Nolet, Wageningen University \& Research, corjan.nolet@wur.nl \\ Marinka van Puijenbroek, Wageningen University \& Research, marinka.vanpuijenbroek@wur.nl \\ Michel Riksen, Wageningen University, michel.riksen@wur.nl \\ Isaac Williams, University of Twente, i.a.williams@utwente.nl
}

\section{INTRODUCTION}

In 2011 a multifunctional peninsula-shaped nourishment project (the Sandmotor) was implemented on the West coast of the Netherlands. Its objectives included an increase in sediment supply towards the dunes to maintain their function as a flood defense on the longterm as well as the development of (temporary) new dune area for nature and recreational purposes.

In this contribution we will present an overview of the observed developments related to aeolian processes at the Sandmotor in the first six years after implementation of the nourishment, as well as discuss the relation of these developments to specific characteristics of the design and management of the Sandmotor.

\section{OBSERVED AEOLIAN DEVELOPMENTS}

The first morphologic developments due to wind-driven sand transport at the Sandmotor consisted of: i) partially infilling of the lake (Fig.1), and the lagoon, predominantly from S-SW direction at a fairly constant rate [1] (still ongoing), ii) foredune development at the toe of the dune reinforcement (which was implemented prior to construction of the Sandmotor) (Fig.2a) at alongshore varying rates [2], iii) scattered, ephemeral embryo dune development in interaction with establishment of annual vegetation. At some locations new incipient foredune ridges started to develop (Fig.2a) and incipient hummocky dunes have recently started to developed away from the primary dune front (Fig. 2b). The latter being initiated by the spontaneous establishment of perennial vegetation tussocks.

\section{DISCUSSION}

The creation of an elevated artificial coastline with dredged seabed material has led to surface armoring which affects the total amount of wind-driven sand supply to the dunes [2]. The location of the lake and lagoon, combined with directional properties of the wind climate, steer an alongshore varying aeolian sediment supply towards the dunes. Potentially, the incipient hummocky dunes may also become a sediment sink area and as such modulate sand supply to the foredunes. The locations of new dune formation away from the primary dune foot are strongly tied to establishment of vegetation which is linked to the design property 'elevation' as this influences frequency of flooding [3]. Also prevailing management practice regarding beach raking, allowed beach traffic, and fencing off of areas with incipient dune formation influenced vegetation establishment.

\section{CONCLUSIONS}

A mega-nourishment like the Sandmotor provides both accommodation space and source material for aeolian dunes to develop. Their observed space-time varying development is related to sediment supply but also clearly

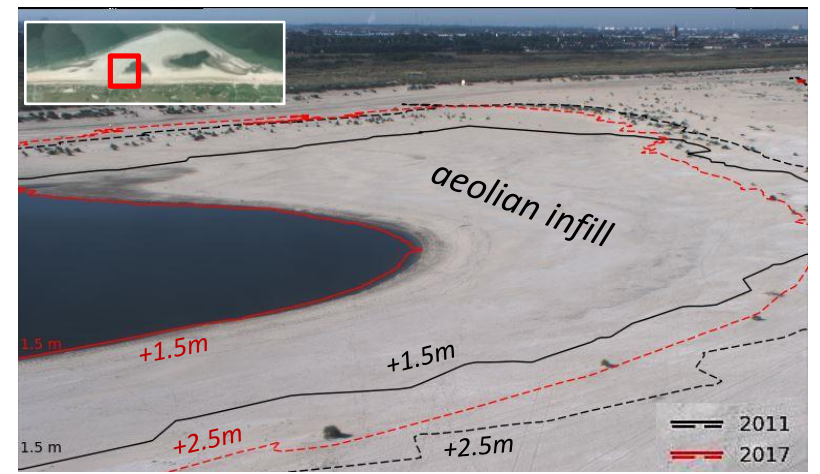

Figure 1 - Aeolian infilling of lake; elevation contours in $\mathrm{m}$ above MSL, projected on Argus video image June 1, 2017.

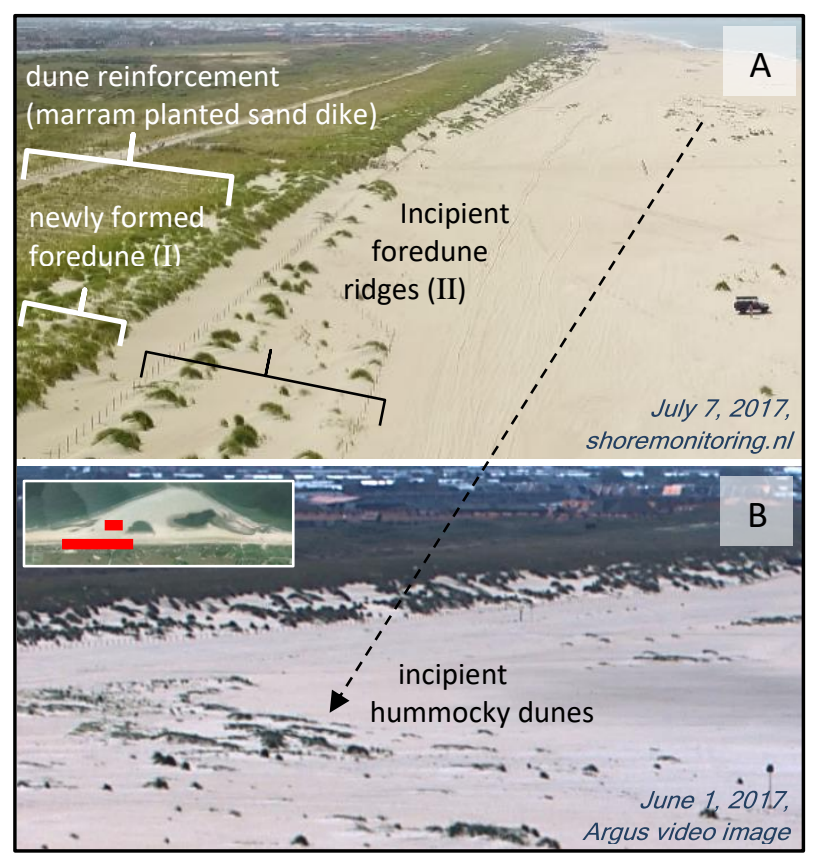

Figure 2 - Example of types of dune formation observed at the Sandmotor (southern part, see inset). A; foredune development near the toe of the dune reinforcement (I) and subsequently formed incipient foredune ridges (II); B: incipient hummocky dunes initiated by perennial vegetation.

tied to establishment dynamics of vegetation, both being tied to the nourishment topography. Vegetation establishment can also be affected by beach management regulations.

\section{REFERENCES}

[1] Van der Weerd, Wijnberg (2015): Aeolian sediment flux derived from a natural sand trap. J.Coast.Res.(75): 338-342. [2] Hoonhout (2016): Aeolian sediment availability and transport. PhD thesis TUDelft.

[3] Van Puijenbroek (2017): Dunes above and beyond: Interaction between ecological and geomorphological processes during early dune development. PhD thesis WUR. 